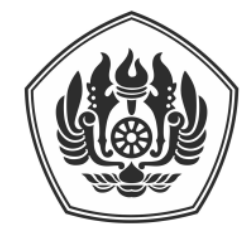

Padjadjaran Journal of International Law

ISSN: 2549-2152, EISSN: 2549-1296

Volume 4, Number 1, January 2020

\title{
Australia's Membership in the Association of Southeast Asian Nations in relation with Human Rights Policies
}

\section{Danielle Putri Ratu*}

\begin{abstract}
Australia, as one of the first dialogue partners of ASEAN has been one of the subjects in a continuous discussion over the need to further integrate Australia within ASEAN and therefore making Australia as one of the Member States of ASEAN. This is accompanied with the idea of advancing the partnership, bearing in mind the many accomplishments that the partnership have yielded. However, there are varying complex issues at hand regarding Australia's membership. A membership would mean compliance with the ASEAN Charter, where it is found to be difficult for Australia in fulfilling all the needed requirements and may restrict Australia in certain fields of concern, one of which is human rights policies. ASEAN is known for its ASEAN Way, which is a noninterference and consensus based method in resolving issues and maintaining peace and security, that includes human rights. This has generated criticism in ASEAN's inability to protect human rights while also failing to hold accountability of human rights law violations. This is also due to the inadequate legal instruments that does not provide a proper protection and prevention of human rights violations. In relation to Australia's membership, this would create a conflicting issue since there are several differences between Australia and ASEAN regarding human rights policies, along with its values. As there seems to be no urgency to integrate Australia as a member into ASEAN, therefore membership is not needed to avoid unwanted conflict and partnership between the party can still be built as dialogue partners.
\end{abstract}

Keywords: ASEAN, Australia, Human Rights Law

\section{Keanggotaan Australia dalam Perhimpunan Bangsa-Bangsa Asia Tenggara dihubungkan dengan Kebijakan Hak Asasi Manusia}

\begin{abstract}
Abstrak
Australia sebagai salah satu negara pertama yang menjadi dialogue partner ASEAN seringkali menjadi subjek diskusi mengenai keinginan untuk mengintegrasikan Australia dengan ASEAN dan kemudian menjadikan Australia sebagai salah satu anggota dari ASEAN. Hal ini disertai pula dengan ide untuk meningkatkan kerja sama yang telah ada, mengingat berbagai keberhasilan yang telah dihasilkan dari padanya. Namun, terdapat beberapa permasalahan yang ada mengenai keanggotaan Australia. Keanggotaan akan berarti kepatuhan terhadap Piagam ASEAN, dimana akan sulit bagi Australia untuk memenuhi semua persyaratan yang ada dan memunculkan kemungkinan bagi Australia untuk terhalangi di beberapa aspek, yang salah satunya merupakan

PADJADJARAN JOURNAL OF INTERNATIONAL LAW Volume 4 Issue 1 Year 2020 [ISSN 2549-2152] [e-ISSN 2549-1296]

Research Assistant at Indonesia Centre of International Law (ICIL), Universitas Padjadjaran, Jl. Imam Bonjol No.21 Bandung, danielle.putri.ratu@gmail.com.
\end{abstract}


hukum hak asasi manusia. ASEAN itu sendiri dikenal dengan ASEAN Way, yang merupakan suatu metode yang didasarkan dengan non-intervensi dan konsensus dalam menyelesaikan masalah dan dalam menjaga keamanan dan kedamaian yang juga berkaitan dengan hak asasi manusia. Hal ini telah memunculkan kritik terhadap ketidakmampuan ASEAN dalam melindungi hak asasi manusia dan meminta pertanggungjawaban atas pelanggaran hukum hak asasi manusia. Hal ini juga dikarenakan instrumen hukum yang tidak memadai karena tidak menyediakan perlindungan dan pencegahan yang cukup terhadap pelanggaran hukum hak asasi manusia. Dihubungkan dengan keanggotaan Australia, maka hal ini akan memunculkan permasalahan yang bertabrakan dimana adanya perbedaan antara Australia dan ASEAN mengenai hukum hak asasi manusia, beserta nilai-nilai yang dipegang. Oleh karena tidak adanya urgensi untuk keanggotaan Australia, maka keanggotaan itu tidak diperlukan demi menghindari konflik yang tidak diinginkan dan kerjasama antara keduanya masih dapat dibangun dengan dasar sebagai dialogue partner.

Kata Kunci: ASEAN, Australia, Hukum Hak Asasi Manusia

\section{A. INTRODUCTION}

Australia and the Association of Southeast Asian Nations (ASEAN) have a long standing history of cooperation. Australia became the first ASEAN dialogue partner since $1974^{1}$ and has had annual dialogues with ASEAN foreign ministers since $1980^{2}$, to this day the two parties have continued to build a strong and impactful partnership in various fields of cooperation. One of the most noteworthy milestones of the ASEAN-Australia cooperation, is the ASEAN-Australia Special Summit 2018 held in Sydney, Australia. Based on the joint statement, The Sydney Declaration, the parties have affirmed and are committed to further strengthen economic and regional security, bearing in mind the increasing relationship between the two. This continuous and impactful relationship has led to conversation on Australia's membership in ASEAN, whether it will be good to boost economic trade and other foreign policies. While it is worth mentioning that indeed Australia has brought a significant contribution in the field of economics with ASEAN countries, there are much more to consider.
The idea of Australia becoming a member in ASEAN is not in particular a newly emerging idea. There are various opinions on how Australia's membership would integrate with ASEAN in various fields of policies, including the field of human rights law. Seeing the precedents of practice and with history in general, it could be pointed out that ASEAN has a specific stance and perspectives on how to resolve and interact in relation with human rights. ASEAN has always drawn criticism in the way it operates in handling various human rights issues of its own Member States, upholding the 'ASEAN way' in every aspect of its resolution. If Australia were to earn a membership in ASEAN, it would have to abide by the Charter and how ASEAN handles disputes in regards to its Member States. This requires a further analysis on how this membership would impact both ASEAN and Australia in terms of human rights.

\section{B. ASEAN-AUSTRALIA PARTNERSHIP}

One of the earliest partnerships between ASEAN and Australia came as early as Australia had become ASEAN first dialogue partner. The ASEAN Australia Economic

1 Australian Government Department of Foreign Affairs and Trade, "Association of Southeast Asian Nations (ASEAN)", https://www.dfat.gov.au/international-relations/regional-architecture/asean/Pages/association-of-southeast-asian-nations-asean, accessed from 13 June 2020.

2 Parliament of Australia, "The ASEAN-Australia Special Summit", Sydney March 2018: issues and implications, https://www.aph.gov.au/About_Parliament/Parliamentary_Departments/Parliamentary_Library/pubs/rp/rp1718/ASEANSummit, accessed from 13 June 2020. 
Human Rights Policies

Cooperation Program (AAECP) was established in 1974, that provided assistance to ASEAN Member States in various forms from agriculture to technology, which ended in 2004. This program has given an added impact in terms of networking in critical points in various sectors within ASEAN and Australia as well. ${ }^{3}$ Moving forward, there was the Australian Mission to ASEAN, which was established in 2013 with an objective to advance Australia's interest with ASEAN and ASEAN-led processes. Further in 2014, Australia entered into a Strategic Partnership while holding a Commemorative Summit and agreed to hold meetings every two years. The first of these meetings was held in Vientiane, September 2016 and followed by the ASEANAustralia Special Summit in Sydney, Australia, March 2018. In observing the cooperation between the two, it is clear that there is an emphasization on economic partnership. One of the works in this field of partnership is the ASEAN-Australia-New Zealand Free Trade Agreement (AANZFTA) in 2009 with aims to improve the business environment and to remove trade barriers. It is as expected, seeing that ASEAN with its 649.1 million in population, have acquired a combined Gross Domestic Product (GDP) double by a decade ago in 2008, which now is valued at US\$3.0 trillion in 2018. This earned ASEAN the position as the world's fifth largest economy, following the United States, China, Japan and Germany. In the period during 2008 to 2018, ASEAN economy has grown steadily with an average annual growth of $5.3 \% .^{4}$ All of this makes ASEAN as an attractive and important economic partner to Australia. The two-way trade between ASEAN and Australia has now amounted to US\$93 billion. ${ }^{5}$ Today, ASEAN

Rodolfo C. Severino, Southeast Asia in Search of an ASEAN Community: Insights from the former ASEAN SecretaryGeneral, Singapore: Institute of Southeast Asian Studies, 2006, p. 311.

4 Association of Southeast Asian Nations, "ASEAN Key Figures 2019", Jakarta: 2019, p. 32. accounts for $11.5 \%$ of Australia's exports and $16.1 \%$ Australia's imports.

In the midst of all the economic interaction, Australia has also contributed in other fields of politics and security and sociocultural cooperation. Australia is a member and supporter of ASEAN Defense Ministers Meeting Plus (ADMM-Plus) and regularly attends the Expanded ASEAN Maritime Forum (EAMF) since 2012. ${ }^{6}$ Australia has continuously supported ASEAN in terms of education through various scholarships offered to ASEAN Member States and in addition, through the ASEAN-Australia Special Summit, Australia has announced new education initiatives such as the Australia Awards ASEAN scholarship and New Colombo Plan ASEAN Fellowship. In regards to assistance in times of disaster, Australia has played a significant role in disaster management with ASEAN, for instance Indonesia and Australia had co-hosted the 2018 EAS International Disaster Assistance Workshop in Australia, where it explored the One ASEAN One Response application beyond the ASEAN region. This clearly shows how much of an impact and how big the involvement of Australia is, in helping the development of ASEAN as a whole, based on the three ASEAN pillars, which are the ASEAN Political-Security Community (APSC), ASEAN Economic Community (AEC) and ASEAN Socio-Cultural Community (ASCC).

In regards to human rights, there have been a few forms of cooperation. Australia had led the Asia Regional Cooperation to Prevent People Trafficking Project from 2003 to 2006, the Asia Regional Trafficking in Persons Project from 2007 to 2012 and the Australia-Asia Program to Combat Trafficking

Australian Government, ASEAN Now: Insight for Australian Business, A report on Australia's trade and investment relationship with ASEAN, Australia, 2017, p. 10

6 Association of Southeast Asian Nations, Overview ASEANAustralia Dialogue Relations, April 2017, para. 12, p. 3. 
in Persons from 2013 to 2018. ${ }^{7}$ These were done in coordination with the ASEAN Senior Official Meeting on Transnational Crime, to support the criminal justice system and to enhance investigative and judicial cooperation in the prosecution of human traffickers. $^{8}$ Additionally, there was the Australia-Asia Program to Combat Trafficking Persons (AAPTIP) that went on from 2013 to 2018, with one of its objectives being "regional bodies enhance regional cooperation and leadership on the criminal justice response to human trafficking in the ASEAN regions." ${ }^{\prime}$ AAPTIP supports the development and implementation of work plans at two levels: ${ }^{10}$

1. National: By supporting annual plans developed by national program steering committees in each partner country.

2. Regional: By supporting the ASEAN Secretariat, the ASEAN Trafficking in Persons Working Group of the Senior Officers Meeting on Transnational Crime and the Head of Specialist Unit process.

There is also the ASEAN-Australia Counter Trafficking (ASEAN-ACT) which was announced in the ASEAN-Australia Special Summit 2018. ASEAN-ACT is a ten years investment from 2018 to 2028, enacted with the objective to further support the ASEAN Member States in implementing ASEAN Convention against Trafficking in Persons, Especially Women and Children (ACTIP). This investment will work with key stakeholders to enhance capability at regional and national

7 Hitoshi Nasu, (et al.), The Legal Authority of ASEAN as a Security Institution, Cambridge: Cambridge University Press, 2019, p. 180.

$8 \quad$ Ibid

9 Australian Government Department of Foreign Affairs and Trade, "Australia-Asia Program to Combat Trafficking in Persons (AAPTIP)", January 2016, p. 1.

10 Ibid.

11 Australian Government Department of Foreign Affairs and Trade, "ASEAN-Australia Counter-Trafficking: Investment Design", March 2018, p. 3. levels with a primary goal to enhance ASEAN Member States' justice system in providing punishment against traffickers whilst protecting the victims' human rights. ${ }^{11}$ Furthermore, there have been a few dialogues that were held between ASEAN and Australia, as the ASEAN Intergovernmental Commission on Human Rights (AICHR) had gone on a study visit to Australia in $2017 .{ }^{12}$ The AICHR also held an interregional dialogue on 4-6 June in Bangkok, which was also attended by the Australian Human Rights Commission. ${ }^{13}$

These highly active and incorporated partnerships have shown how much both ASEAN and Australia are keen to build and strengthen these partnerships. Looking at the impact given by both countries to each other, it seems unlikely that both parties will part ways any time soon. This condition has prompted the ideas of further integration of Australia as a member State of ASEAN itself. While it is economically convincing, the issue of human rights still begs a question.

\section{AUSTRALIA MEMBERSHIP IN ASEAN}

The ASEAN Charter regulates the admission of new members on Article 6 . There are a few criteria which have to be fulfilled by states to be admitted, which are:

1. location in the recognized geographical region of Southeast Asia;

2. recognition by all ASEAN Member States;

3. agreement to be bound and to abide by the Charter; and

12 Association of Southeast Asian Nations, "ASEAN, Australia Human Rights Commissions to foster closer relations", https://asean.org/asean-australia-human-rightscommissions-to-foster-closer-relations/, accessed on $12^{\text {th }}$ of December 2019.

13 Association of Southeast Asian Nations, "ASEAN promotes human rights-abiding business practices", https://asean.org/asean-promotes-human-rights-abidingbusiness-practices/, accessed on 12 ${ }^{\text {th }}$ of December 2019. 
4. ability and willingness to carry out the obligations of Membership. ${ }^{14}$

In order for Australia to be admitted as an ASEAN Member State it would have to fulfill all these criteria under the Charter with no exception.

As evident by the Charter, ASEAN has a geographical approach in expanding its membership and not a norm-based criterion such as the European Union's membership. ${ }^{15}$ Therefore, it would be necessary to first identify what constitutes Southeast Asia in accordance with the Charter's requirement. The term Southeast Asia, started to gain momentum from the creation of the Association of Southeast Asia in 1961. The United Nations and ASEAN itself refer to Southeast Asia as an area that is covered by the states of Brunei Darussalam, Cambodia, Indonesia, Laos, Malaysia, The Philippines, Singapore, Myanmar, Thailand and Vietnam. By definition, it seems unlikely that Australia will be considered as a part of Southeast Asia. However, there are opinions to accept New Zealand alongside Australia to recognize the region as a part of Southeast Asia, bearing in mind the immense benefit both will bring in the progress and development of ASEAN. ${ }^{16}$ Even so, there is the issue of identity, if Australia would merge with the Asian identity alongside other Member States where it is clearly objectively different. Adding to that is the condition of the Member State itself. While it is acknowledged that the whole of ASEAN is economically advantageous, individually, most ASEAN Member States have a differing quality in terms of political,

14 Article 6 of The Association of Southeast Asian Nations Charter (ASEAN Charter), 2007.

15 William Maley, "Governance in Australian Discourse" in the ASEAN-India-Australia: Towards Closer Engagement in a New Asia compiled by William T. Tow and Chin Kin Wah, Singapore: Institute of Southeast Asian Studies, 2009, p. 253.

16 Grame Dobell, "Australia as a Full ASEAN Community partner", https://www.aspistrategist.org.au/australia-fullasean-community-partner/, accessed on $12^{\text {th }}$ of December 2019. social and economic condition in contrast with Australia, and one of those is human rights. Furthermore, ASEAN was built under the same region with similar conditions and sharing the same vision, where this could be traced back to the formation of the organization during the Cold War itself. As ASEAN was formed by nations that had looked for protection and had the intent to distance themselves from the issue at hand, whereas Australia had the perspective of having a "forward defence" alongside the United States. ${ }^{17}$ Bearing all these differences, Australia has much to consider if it is willing to share those as well.

In regards to Australia's recognition as a Member State, there have been varying responses from other Member States. Back in 1997, former President Fidel Ramos of the Philippines had mentioned the idea of Australia's membership and in 1996 former Singapore's Prime Minister Goh Chok Tong had issued the possibility of Australia becoming a member of ASEAN. ${ }^{18}$ Moreover, the Former Malaysian Prime Minister, Mahathir Mohamad had disagreed with the idea, but following that, he implied that Canberra might have earned the right to join. Former Singaporean Foreign Affairs Deputy Secretary, Kishore Mahbubani, had also mentioned the benefit of further integrating Australia into ASEAN. ${ }^{19}$ In addition, the President of Indonesia, Joko Widodo, when interviewed at the ASEAN-Australia Special Summit 2018 had agreed to the idea of Australia membership in ASEAN. The president also adds that it would be beneficial

17 Sally Percival Wood and Baogang He, The Australia-ASEAN Dialogue, United States: Palgrave Macmillan, 2014, p. 3.

18 Frank Frost, Engaging the Neighbours: Australia and ASEAN since 1974, Australia: The Australian National University Press, 2016, pp. 182-183.

19 Republic of the Philippines Foreign Service Institute, "The Challenges to Australia's ASEAN Membership", http://www.fsi.gov.ph/the-challenges-to-australiasasean-membership/, accessed on 12 ${ }^{\text {th }}$ of December 2019. 
in terms of stability, particularly economic stability and political stability. ${ }^{20}$ Despite these positive remarks, it is still rather difficult to make a definite conclusion whether all 10 Member States would want to recognize and accept Australia as a part of ASEAN.

By being an ASEAN Member State, the ASEAN Charter will be legally binding towards Australia. In turn, this will result in Australia's responsibility to carry out its obligation under the Charter and under any other ASEAN legal instruments, as mentioned in Article 5 of the Charter of the rights and obligations of the members:

1. Member States shall have equal rights and obligations under this Charter.

2. Member States shall take all necessary measures including the enactment of appropriate domestic legislation, to effectively implement the provisions of this Charter and to comply with all obligations of membership. ${ }^{21}$

The enactment of these obligations include those relating to human rights. Australia would have to implement and take measures under several ASEAN human rights instruments. One of the main ASEAN legal instruments for human rights is the AICHR. The earliest ones being the ASEAN Declaration Against Trafficking in Persons, Particularly Women and Children in 2004, The Criminal Justice Responses to Trafficking in Persons in 2007, ASEAN Leaders Joint Statement in Enhancing Cooperation against Trafficking in Persons in Southeast Asia in 2011 and the notably ASEAN Human Rights Declaration (AHRD) in 2012.

20 The Guardian, "Indonesia says it would be a 'good idea' for Australia to join ASEAN", https://www.theguardian.com/world/2018/mar/16/indo nesia-says-it-would-be-a-good-idea-for-australia-to-joinasean, accessed on $12^{\text {th }}$ of December 2019.

21 Article 5 of ASEAN Charter.

22 Mely Caballero-Anthony, Regional Security in Southeast Asia Beyond the ASEAN Way, Singapore: Institute of Southeast Asian Studies, 2005, p. 2.

23 Mikio Oishi, Contemporary Conflict in Southeast Asia: Towards a New ASEAN Way of Conflict Management,

\section{THE 'ASEAN WAY' ON HUMAN RIGHTS AND AUSTRALIA}

There has been no official or legal definition provided in defining the term 'ASEAN Way'. However most scholars have defined the term as an encapsulation of the norms, principles and practices of which ASEAN maintains its inter-state relations in managing conflicts and maintaining peace and security in Southeast Asia. ${ }^{22}$ The ASEAN way is essentially a symbolism and indirect approaches to prevent its members internal conflicts from becoming internationalized. ${ }^{23}$ This includes institutions, dialogue and consultations, consensus based decision making and noninterference in each members' internal matters. ${ }^{24}$ It is also the preference for informality and loose arrangements, and dependence on personal relations among leaders, ministers and officials and on peer influence. ${ }^{25}$ Certainly, this procedure does not exclude the way human rights policies are being approached by ASEAN, as it has been evident through the various responses in terms of any of its member states internal human rights issues and the human rights instrument available in ASEAN itself. Where if Australia were to become a member, needless to say, it has to adhere with the ASEAN Way in its approach to human rights matters.

\section{Non-Interference}

Under the ASEAN Political-Security Community, there is the ASEAN Intergovernmental Commission on Human

Singapore: Springer, 2016, p. 20; Shaun Narine, Explaining ASEAN: Regionalism in Southeast Asia, United States of America: Lynne Rienner Publishers, 2002, p. 31.

24 Alison Duxbury and Hsien Li-Tan, Can ASEAN Take Human Rights Seriously?, United Kingdom: Cambridge University Press, 2019, p. 124; Jurgen Haacke, ASEAN's Diplomatic and Security Culture: Origins, Development and Prospects, London: Routledge Curzon, 2003, p. 3-4.

25 Rodolfo C. Severino, Op.Cit., p. 11. 
Rights that was established on 23 October 2009, at the 15th ASEAN Summit in Thailand. The AICHR is committed to strengthening regional cooperation on human rights. The more elaborated purpose of $\mathrm{AICHR}$ is mentioned in the AICHR Term of References, as follows:

1. To promote and protect human rights and fundamental freedoms of the people of ASEAN;

2. To uphold the right of the people of ASEAN to live in peace dignity and prosperity;

3. To contribute to the realiation of the purposes of ASEAN as set out in the ASEAN Charter in order to promote stability and harmony in the region, friendship and cooperation among welfare and participation of ASEAN peoples in the ASEAN Community building process;

4. To promote human rights within the regional context, bearing in mind national and regional particularities and mutual respect for different historical, cultural and religious backgrounds and taking into account the balance between rights and responsibilities;

5. To enhance regional cooperation with a view to complementing national and international efforts on the promotion and protection of human rights; and

6. To uphold international human rights standards as prescribed by the Universal Declaration of Human Rights, the Vienna Declaration and Programme of Action, and international human rights instruments to which ASEAN Member States are parties. ${ }^{26}$

Moreover, the AICHR also mentioned that it shall be guided by the principles encumbered in Article 2 of the ASEAN Charter, these principles are:

Association of Southeast Asian Nations, Terms of Reference of ASEAN Intergovernmental Commission on Human Rights, July 2009, p. 1.
1. Respect for the independence, sovereignty, equality, territorial integrity and national identity of all ASEAN Member States;

2. Non-interference in the internal affairs of ASEAN Member States;

3. Respect for the right of every Member State to lead its national existence free from external interference, subversion and coercion;

4. Adherence to the rule of law, good governance, the principles of democracy and constitutional government;

5. Respect for fundamental freedoms, the promotion and protection of human rights, and the promotion of social justice;

6. Upholding the Charter of the United Nations and international law, including international humanitarian law, subscribed to by ASEAN Member States; and

7. Respect for different cultures, languages and religions of the people of ASEAN, while emphasizing their common values in the spirit of unity in diversity. ${ }^{27}$

Among the varying principles that are upheld by ASEAN, the particular principle of non-interference is one of the main reasons for the often passive actions that ASEAN takes against its Member States. Indeed, ASEAN has attained a rather silent approach in human rights violation amongst its members, often classifying it as an internal affairs. ${ }^{28}$ Interventions are usually done in a bilateral manner, rather than acting as a collective through ASEAN to avoid any disharmony within its

27 Ibid., p. 2

28 Malcolm Cook and Daljit Singh, Southeast Asian Affairs 2020, Singapore: ISEAS Publishing, 2020, p. 12. 
members. ${ }^{29}$ In regards to the principle of non-interference, Mutaqin had observed:

"However, in the context of ASEAN, the principle of noninterference, which is rooted in the principle of non-intervention in international law, is Janus-faced: on the one side, it has created a secure and stable region that has led to unprecedented economic development; on the other side, this has made ASEAN indifferent to the gross violations of human rights committed internally by individual Member States like Myanmar. ${ }^{1130}$

In relation to Australia, several writings have also taken up on this issue, that if Australia were to be a member of ASEAN then it would have to refrain from criticizing against the other actions of the other ASEAN Member States. ${ }^{31}$

\section{Dispute Settlement}

Where there is an attempt to discuss human rights violations, it is known of the difficulties to reach a result in ASEAN's way of resolving a dispute. The ASEAN Charter on Article 2(d) regarding principles, had set out that in terms of disputes, the Member States shall rely on peaceful settlements. Moreover, as stipulated in

29 Alison Duxbury and Hsien Li-Tan, Can ASEAN Take Human Rights Seriously?, United Kingdom: Cambridge University Press, 2019, p. 131.

30 Zezen Zaenal Mutaqin, "The Rohingya Refugee Crisis and Human Rights: What Should ASEAN Do?", Asia-Pacific Journal on Human Rights and the Law, Vol. 19, No. 1, 2018, p. 24.

31 Danielle Keeton-Olsen, "Australia Targets an ASEAN Alliance, But Disagreements Over Human Rights Could Slow Its Progress", https://www.forbes.com/sites/daniellekeetonolsen/2018 /03/16/australia-targets-an-alliance-with-asean-despitelingering-human-rights-questions/\#5a82f9855cf1, accessed on $12^{\text {th }}$ of December 2019; Luke Hunt, "Australia in ASEAN: An Ever-Floating Idea Without a Clear Case?", https://thediplomat.com/2019/08/australia-in-asean-anever-floating-idea-without-a-clear-case/, accessed on $13^{\text {rd }}$ of December 2019.
Chapter 7 of the Charter, in Article 22(1), it reads that as a general principle in the settlement of disputes, Member States shall resolve disputes through dialogue, consultation and negotiation. In addition, Article 26 regulates that in the situation of an unresolved dispute, the dispute would then be referred to the ASEAN Summit to reach its decision where the Charter does not specify what action the summit may take, but has been described as unsatisfactory due to the predominant nature of consensus. ${ }^{32}$ Furthermore, the ASEAN Summit is more of a policy-making body and not a court or arbitral tribunal, where it is likely that it may only encourage further peaceful settlement or encourage compliance with a decision from a dispute settlement mechanism. ${ }^{33}$ The Charter also does not provide any means of punitive measures for violations of obligations or violations of the Charter itself. ${ }^{34}$ Nevertheless, the ASEAN Member States have also shown a preference in resorting to bilateral dialogues or diplomacy for an intra-regional dispute resolution, and when it is not sufficient, Member States tend to turn to international courts over regional mechanisms such as ASEAN, for adjudication. ${ }^{35}$ Another concern is that, while ASEAN tend to refer to hard law for

32 Gino J. Naldi, "The ASEAN Protocol on Dispute Settlement Mechanisms: An Appraisal", Journal of International Dispute Settlement, Vol. 5, No. 1, 2014, p. 121.

33 Hao Duy Phan, "Procedures for Peace: Building Mechanism for Dispute Settlement and Conflict Management with ASEAN", U.C. Davis Journal of International Law \& Policies, Vol. 20, No. 1, 2013, p. 57.

34 Gino J. Naldi, Op.Cit., p. 116.

35 Robert Beckman (et al.), Promoting Compliance: The Role of Dispute Settlement Mechanisms in ASEAN Instruments, United Kingdom: Cambridge University Press, 2016, p. 36; Ramses Amer, "The Conflict Management Framework of the Association of Southeast Asian Nations (ASEAN)" in the Conflict Management and Dispute Settlement in East Asia, compiled by Ramses Amer and Keyuan Zou, United States of America: Routledge, 2016, p. 53-54. 
Australia's Membership in the Association of Southeast Asian Nations in Relation with Human Rights Policies

economic cooperation, human rights matters are often approached with much more flexibility. ${ }^{36}$

In the case of AICHR, while it is mandated to promote the realization of human rights instruments, it does not have the functions that are truly necessary for human rights protection in regards to dispute settlement, for example individual petition system, powers of investigation or monitoring and reporting, ${ }^{37}$ on site visit to appraise situations, procedure to accept complaints from victims and to offer related redress. ${ }^{38}$ All this is due to the heavy reliance on the peaceful consensus method of decision making and also the principle of non-interference that has made it difficult for ASEAN to have a mechanism of protection to resolve any regional conflicts by its own Member States. ${ }^{39}$ To this, Muntarbhorn argues:

"While there may be some merit to the ASEAN Way in terms of peaceful discourse, it does not solve the problem of intransigence on the part of those who fail to respect human rights and for whom gentle admonition will not work. After all, major human rights violations are tantamount to crimes and they need to be dealt with proportionately and accountability."

On a positive note, the consensus method is not in any way a specific 'negative' trait of how ASEAN operates. As observed by Severino in regards to how a consensus is reached within ASEAN, that not all members need to agree explicitly, a

Ibid., p. 47

Alison Duxbury and Hsien Li-Tan, Op. Cit., p. 175.

38 Vitit Muntarbhorn, Unity in Connectivity: Evolving Human Rights Mechanisms in the ASEAN Region, The Netherlands: Koninklijke Brill NV, 2013, p.174.

39 Michael Leach and Sally Percival Wood, "Timor-Leste: From INTERFET to ASEAN" in The Australia-ASEAN Dialogue, compiled by Sally Percival Wood and Baogang He, United States: Palgrave Macmillan, 2014, p. 72.

40 Vitit Muntarbhorn, Op. Cit., p. 171. consensus will only be blocked when one or more members considers the proposal to be dangerous to their national interest thus opposing the proposal. ${ }^{41}$ This method is actually similar to what has been practiced by the UN General Assembly and other UN bodies. ${ }^{42}$ Further, in terms of bilateral efforts in settling a dispute, it can still be facilitated through the conflict management created by ASEAN as a facilitator in creating conducive conditions to increase interactions in promoting better relations among its Member States. ${ }^{43}$ Therefore, what's important in implementing ASEAN's preferred method of dispute settlement, is that it shall not be operated in a way that it hinders the enforcement of human rights law and ASEAN's principles when it is being confronted by any human rights issues.

\section{International Human Rights Law}

By examining each of the current Member States compliance with the 18 cores international human rights treaties along with its complementary optional protocols, shows that there is room for further improvement. It is of importance for a State in ratifying international human rights treaties as it reflects the consent to be legally bound by the treaty and in realising the rights recognized by the treaty, ${ }^{44}$ while also requiring to periodically report on their implementation to ensure that there is a measure of accountability between human rights legislations and the implementations. ${ }^{45}$ Unfortunately, 6 of

\footnotetext{
Rodolfo C. Severino, Op.Cit., p. 34.

Ibid.

Ramses Amer, Op.Cit., p. 57.

44 United Nations Human Rights Instruments, Reports on indicators for monitoring compliance with international human rights instruments (UN Doc HRI/MC/2008/3, 6 June 2008), p. 34.

45 Hilary Stauffer, "ASEAN and the Evolving State of Human Rights", Social Space, 2011, p. 70.
} 
the current Member States have only ratified half and even less of the 18 international human rights treaties and its optional protocols, with Singapore, Malaysia and Myanmar having only 5 ratification, as the Member States with the least amount of treaties ratification. The highest amount of ratification of human right treaties and its optional protocols among the ASEAN Member States was done by the Philippines, amounting to 14 ratifications, which is the same exact amount that Australia has ratified. ${ }^{46}$ Nevertheless, it should be noted that the more amount of ratification or signatory of human rights treaties done by a State, does not guarantee an assurance of protection for human rights in that specific State.

In regards to national implementation, some examples can be seen in the national constitution of the Member States. While Member States do have national constitutions and other domestic regulations governing human rights, there is a considerable degree of differences as to what type of limitation that each State applied and some does not even have any constitutional guarantee of human rights. To this, Duxbury and Tan provided an insight:

"If rights are to permeate the regional community it is important that ASEAN members not only adopt constitutional provisions protecting rights (whether they be civil and political rights or economic, social and cultural rights), but also that such rights are genuinely safeguarded in members' societies. It is also important that members have some

\footnotetext{
46 United Nations Human Rights Commissioner, Status of Ratification Interactive Dashboard, https://indicators.ohchr.org, accessed on $30^{\text {th }}$ of December 2019.

47 Alison Duxbury and Hsien Li-Tan, Op. Cit., p. 111.
}

level of common or baseline understanding, or at least a process for coming to that understanding, of the rights they regard as fundamental." 47

There is however, the existence of AHRD. The declaration has established a framework for human rights development and cooperation between the members of ASEAN. It contains provisions on 'civil and political rights', 'economic, social and cultural rights', 'right to development' and 'right to peace'. One of the declaration's clauses that has faced criticism from civil society organization and the international community, is Article 8 of the AHRD, regarding limitations which stipulates that "The human rights and fundamental freedoms of every person shall be exercised with due regard to the rights and duties of others. The exercise of human rights and fundamental freedoms shall be subject only to such limitations as are determined by law solely for the purpose of securing due recognition for the human rights and fundamental freedoms of others and to meet the just requirements of national security, public order, public health and public morality and the general welfare of the peoples in a democratic society." This particular limitation was criticized because it was placed under 'General Principles' rendering it to potentially apply to all rights including those which would be non-derogable under international human rights law. ${ }^{48}$ Some were concerned with the inclusion of public morality as a form of limitation due to the risk of marginalization for women and vulnerable groups. ${ }^{49}$ However it is also argued that other conventions on

48 Catherine Shanahan Renshaw, "The ASEAN Human Rights Declaration 2012", Human Rights Law Review, Vol. 13, Issue 3, 2013, p. 569.

49 Ibid; Marcella Ferri, "The ASEAN Declaration of Human Rights as a Case of Human Rights Translations" in the Human Rights in Translations: Intercultural Pathways 
Australia's Membership in the Association of Southeast Asian Nations in Relation with Human Rights Policies

human rights have also provided limitations in reference to national laws, whereas most national constitutions of ASEAN Member States does in one form or another provide limitations of rights based on public morality. ${ }^{50}$

Moreover, in 1993, ASEAN had already expressed similar perception, stressing a "due regard for specific cultural, social, economic and political circumstances" in relation to the protection and promotion of human rights" where Severino provides that this is due to the difference ASEAN countries and other States. ${ }^{51}$ For instance, the death penalty are encumbered in all the Member States criminal law and caning is also allowed in several Member States, of which these would be forms of violations of human rights in other regions such as the European Union. ${ }^{52}$ In comparison with Australia, the State is opposed and has abolished the death penalty in 1985 and prohibited the reintroduction of capital punishment in $2010 .^{53}$ While on a similar note, Australia has also acknowledged limitations based on public morality in regards to the right to freedom of opinion and expression contained in the International Covenant on Civil and Political Rights. ${ }^{54}$

Nevertheless, article 39 provides for "ASEAN Member States share a common interest in and commitment to the promotion and protection of human rights and fundamental freedoms which shall be achieved through, inter alia, cooperation

compiled by Michal Jan Rozbicki, United States of America: Lexington Books, 2018, p. 181.

Catherine Shanahan Renshaw, Op.Cit., p. 570.

Rodolfo C. Severino, Op.Cit., p. 150.

Ibid.

Australian Government Department of Foreign Affairs and Trade, "Australia's Strategy for Abolition of Death Penalty", https://www.dfat.gov.au/internationalrelations/themes/human-rights/Pages/australiasstrategy-for-abolition-of-the-death-penalty, accessed on $12^{\text {th }}$ of December 2019. with another as well as with relevant national, regional and international institutions or organizations, in accordance with the ASEAN Charter" and article 40 of the AHRD had set out that, "Nothing in this Declaration may be interpreted as implying for any State, group or person any right to perform any act aimed at undermining the purposes and principles of ASEAN, or at the destruction of any of the rights and fundamental freedoms set forth in this Declaration and international human rights instruments to which ASEAN Member States are parties." ${ }^{155}$ Both articles regarding cooperation in the promotion and protection of human rights would need legitimate support by Member States in enacting domestic legislations and international human rights issues, to be able to realize the purpose of AHRD. This is to refrain from further criticism and to elevate actual changes, as observed by Doyle:

"In respect of other ASEAN States, the AHRD does not achieve a localglobal reconciliation but rather an ossification of their sceptical position on human rights with little evidence of 'novel' rights reflecting 'regional particularities'. It is difficult to resist the conclusion that at present the ASEAN human rights mechanism is to play little more than a mollifying role in the societies of SEA and beyond."156

54 Australian Government Attorney-General's Department "Right to freedom on opinion and expression", https://www.ag.gov.au/rights-and-protections/humanrights-and-anti-discrimination/human-rightsscrutiny/public-sector-guidance-sheets/right-freedomopinion-and-expression, accessed on $12^{\text {th }}$ of December 2019.

55 Article 40, ASEAN Human Rights Declaration, 2012.

56 Nicholas Doyle, "The ASEAN Human Rights Declaration and The Implications of Recent Southeast Asian Initiatives in Human Rights Institution-Building and Standard Setting", The International and Comparative Law Quarterly, Vol. 63, 
However, while it is not in particular a binding legal instrument for its Member States, the declaration does provide a stepping stone of change. It is certainly a start in laying down an agreed international standard of human rights amongst its Member States, where it should be pointed out that the standard set out in the AHRD is different from the Western philosophy on human rights, where it upholds individualism. In comparison with the AHRD itself, it is inspired by the Asian philosophy in regards to rights, which emphasizes a collective connection between an individual and the community. ${ }^{57}$ This is specifically set out in Article 17 of the AHRD, "All human rights are universal, indivisible, interdependent and interrelated. All human rights and fundamental freedom in this Declaration must be treated in a fair and equal manner, on the same footing and with the same emphasis." ${ }^{18}$ As such, the existence of AHRD itself provides an assurance that at the very least ASEAN Member States will no longer be able to denounce human rights as a Western imposition. ${ }^{59}$ Therefore, while the AHRD is mainly declaratory in nature, it can be seen as a form of agreed standard of legal recommendation between the parties with commonly shared historic values and philosophy that may encourage further implementation and actualization of concrete actions by the ASEAN Member States.

No. 1, 2014, p. 98; Jacyln L. Neo, "Realizing the Right to Freedom of Thought, Conscience and Religion: The Limited Normative Force of the ASEAN Human Rights Declaration", Human Rights Law Review, Vol. 17, No. 4, 2017, p. 732.

57 Gino J. Naldi and Konstantinos D. Magliveras, "The ASEAN Human Rights Declaration" International Human Rights Law Review, Vol. 3, No. 3, 2014, p. 187.

58 Article 17 of ASEAN Human Rights Declaration 2012.

59 Jacyln L. Neo, Op.Cit., p. 735.

60 Frank Frost, Op. Cit., pp. 51-53.

\section{International Refugee Law}

The issue regarding refugees between ASEAN Member States is not an unknown matter. As early as 1975, ASEAN members at the time were struggling due to the overflowing Indochina refugees which had also impacted Australia. ${ }^{60}$ However in recent years, there exists a developing issue in regards to the Rohingya crisis currently happening in Myanmar. The Rohingya people is a Muslim minority that is currently facing systematic discrimination, statelessness and targeted violence in Rakhine State of Myanmar. ${ }^{61}$ According to Mutaqin there are three levels of concern regarding the Rohingya crisis which are:

1. A focus on persecution and nationality in Myanmar,

2. The issue of statelessness and displacement in the region; and

3. Grave human rights violations amounting to international crimes including genocide and crimes against humanity.

Despite the scale and gravity of the issue, ASEAN is again relying on the ASEAN Way of non-interference. Although, it was after much international pressure that ASEAN members eventually expressed their stance regarding the military government in Myanmar. ${ }^{62}$ Granted, ASEAN had initiated dialogue with Myanmar regarding refugee influx but did not specifically touch on the subject regarding Myanmar's policy towards the Rohingya people. ${ }^{63}$ Member States like Indonesia and Malaysia have also tried to

61 United Nations Office for the Coordination of Humanitarian Affairs, "Rohingya Refugee Crisis", https://www.unocha.org/rohingya-refugee-crisis, accessed on $29^{\text {th }}$ of December 2019.

62 Alison Duxbury and Hsien Li-Tan, Op. Cit., p. 131.

63 Rubiat Saimun, "ASEAN's Rohingya Dilemma: Limits of Regional Co-operation" in the Charting a Sustainable Future of ASEAN in Business and Social Sciences compiled by Naginder Kaur and Mahyudin Ahmad, Singapore: Springer, 2020, p. 340. 
take a proactive role in the crisis, however it was unsuccessful due to ASEAN's lack of consensus. ${ }^{64}$ This lack of clarity from ASEAN regarding the Rohingya crisis, has shown that ASEAN is unable to hold Myanmar accountable.

In terms of refugee regulation, the AHRD stipulated in Article 16, that "Every person has the right to seek and receive asylum in another States in accordance with the laws of such States and applicable international agreements." 65 While the mention of the right to seek asylum is a notable achievement, the practice of it is not as it is on paper. Despite having one of the fastest growing refugees crises in the world. ${ }^{66}$ There are only 3 ASEAN Member States that have ratified the 1951 Convention Relating to the Status of Refugees and the 1967 Protocol, namely Cambodia, Philippines and Timor-Leste. ${ }^{67}$ It is as expected, since most Asian countries are considered to be a persistent rejector of international refugee law, arguing that would put on pressure for poorer or developing countries, while relieving wealthier States from providing humanitarian assistance. ${ }^{68}$

Another explanation provides that most Member States are reluctant in their willingness to commit to international refugee law, in relation to the ASEAN Way of non-interference, as it argues that international refugee law would violate the principle of 'good neighbourliness'. ${ }^{69}$ This is of particular concern, adding to the fact that most Member States do not have

Ibid.

Article 16 of ASEAN Human Rights Declaration 2012

66 United Nations High Commissioner for Refugees, Global Appeal 2018-2019, Switzerland: UNHCR, 2018, p. 84.

67 United Nations High Commissioner for Refugees, States Parties to the 1951 Convention Relating to the Status of Refugees and the 1967 Protocol, April 2015.

68 Amy Nethery, "Australia, ASEAN and Forced Migration" in The Australia-ASEAN Dialogue, compiled by Sally Percival Wood and Baogang He, United States: Palgrave Macmillan, 2014, p. 113 any specific national legislations governing refugees and therefore further risking the matter at hand. On the contrary, Australia is a party to both the 1951 Convention and the 1967 Protocol. Australia is also equipped with comprehensive national legislation for refugees and is able to provide an adequate place of refuge, as it had ranked third for refugees resettlement in 2018. ${ }^{70}$

\section{Australia's Role}

Undoubtedly, Australia has done a number of contributions to the human rights issue within the region of ASEAN. For instance, the notable Comprehensive Plan of Action for Indochinese Refugees (CPA) established in 1989 was done between Vietnam and Laos as countries of origin, Hongkong and ASEAN members as first asylum countries, and third countries for resettlement that includes Australia. ${ }^{71}$ The CPA was deemed a successful agreement in facilitating the process and resettlement of refugees. ${ }^{72}$ Moreover, after the 2010 elections in Myanmar, Australia had given strong support for change in the country, which is of interest to ASEAN and further helped by pressing the European Union to lift the sanctions that had been put over Myanmar at the time. ${ }^{73}$ There were also several forums regarding the matter on human rights of which Australia and ASEAN were involved, such as the ASEAN DGICM + Australia Consultation, Bali Process on People Smuggling, Trafficking in Persons and

69 Sara E. Davis, Legitimising Rejection: International Refugee Law in Southeast Asia, The Netherlands: Martinus Nijhoff Publishers, 2008, p. 9.

70 United Nations Human Rights Commissioner for Refugees, Global Trends Forced Displacement in 2018, Switzerland: UNHCR, 2019, p. 32.

71 Amy Nethery, Op.Cit., p. 114.

72 Ibid.

73 Frank Frost, Op. Cit., p. 171. 
Related Transnational Crime and the AsiaPacific Consultation on Refugees, Displaced Person and Migrants. ${ }^{74}$

However, it should be noted that in terms of confrontation of human rights issues in the Southeast Asia region, the Australian Government has yet to do much in terms of forwardly criticizing ASEAN's lack of action. Whereas there had been hope for Australia to lead or rather insist the ASEAN leaders to confront its humanitarian issues. In the time leading up to the event of the ASEAN-Australia Special Summit 2018, Australian Prime Minister Malcolm Turnbull had been urged to bring human rights as one of the main discussions on the event and to further offer not only humanitarian aid, but to offer assistance in regards to reform efforts. ${ }^{75}$ Unfortunately, the joint statement of the ASEAN-Australia Special Summit had no mention regarding this particular topic.

Based on the factual action insofar by the Australian Government itself, if Australia were to earn a membership within ASEAN, there seem to be less significant change in terms of human rights than one might expect. It would be a legal and political challenge in itself to tackle the long lasting tradition of the principle of non-interference and to change the 10 Member States' way of approach in confronting human rights law violations in the region. Adding to the fact that the method of preference in the confrontations of violations in regards to human rights law, was due to the complex historical element and Asian philosophy of

4 Australian Government, Submission by the Department of Immigration and Citizenship to the Joint Standing Committee of Foreign Affairs and Trade in Relation to Inquiry into Australia's Relationship with ASEAN, 2008.

75 Human Rights Watch, "Australia: ASEAN Summit Should Promote Rights", https://www.hrw.org/news/2018/03/14/australia-asean- rights, which differs with the Western philosophy's perspective. Consequently, by remaining as a dialogue partner, Australia still have the right to choose a legal or political partnership that it wishes to enter; however a membership would mean that Australia would have to abide by all rules and in relation with human rights, it would have to consider various human rights issues in Southeast Asia as an internal affair and further staying silent on the matter.

\section{E. CONCLUSION}

The position of Australia serving as a dialogue partner with ASEAN has already amounted to varying achievements and progress. As can be seen in the history of the dialogues between the two parties, Australia has an immense contribution in all of ASEAN pillars. Through the Joint Statement of the ASEAN-Australia Special Summit: The Sydney Declaration, Australia had committed to further continue its dialogue with ASEAN and cooperate on the implementation of the Plan of Action to Implement the ASEAN-Australia Strategic Partnership. ${ }^{76}$ The plan of action implemented from 2020 to 2024, covers an extensive cooperation ranging from political and security cooperation, economic cooperation, socio-cultural cooperation and cross-pillars cooperation, that would be supported by the funding mechanisms available through the Australian and ASEAN governments. ${ }^{77}$ Showing even more anticipated contribution by Australia in assisting ASEAN with various aspects.

summit-should-promote-rights, accessed on $12^{\text {th }}$ of December 2019.

76 Association of Southeast Asian Nations, Joint Statement of The ASEAN-Australia Special Summit: The Sydney Declaration, 18 March 2018, para. 28, p. 8.

77 Association of Southeast Asian Nations, Plan of Action to Implement the ASEAN-Australia Strategic Partnership (2020-2024), 1 August 2019. 
The human rights policies and the dispute settlement of ASEAN itself will likely remain the same unless there are serious changes of the view of ASEAN Member States and an actual commitment for concrete actions. As strong as the partnership between Australia and ASEAN is, it would hardly suffice to modify or improve the way human rights policies are being approached in the organization. Bearing in mind both parties' differing ways of operating in terms of human rights, it would create a difficult problem when the two have a conflicting approach to a human rights issue where Australia would then have to be in conformity with ASEAN way of approach. This is as expressed by the Australian Government of the Department of Foreign and Trade, that a membership would require Australia to accept ASEAN in discussion with external parties such as other States or with an international organization. ${ }^{78}$ Therefore, arguing that in terms of human rights policies between ASEAN and Australia, it is sufficient to respect the differing historical background and human rights belief between the two parties, thus not requiring Australia to obtain an official membership in ASEAN.

As of now, there seems to be no immediate urgency of the need to further integrate Australia as an official Member State in ASEAN, be it in relation to human rights or other fields of interests. The partnership cooperation between the two parties have been beneficial and there seem to be no major hindrance in regards to Australia's position as a dialogue partner. Australia and ASEAN are still keen to further commit in intensifying their strategic partnership. In terms of human rights, as mentioned before, there would not be much of a difference if Australia were to join ASEAN. Adding with the geographic and identity differences, Australia is better to remain as a dialogue partner rather than a member.

In addition, Australia and ASEAN should continue its partnership and further enhance what's already been established and proven to be beneficial for both parties. While the idea of Australia being a Member State of ASEAN is rather compelling in regards to the huge economic impact that it might provide, there really is no immediate or urgent need to change the status of Australia relations with ASEAN as it is. It has been shown and proven that by just being a dialogue partner, Australia could still build a strong partnership with ASEAN in every aspect of the ASEAN pillars. In relation to human rights, as there has been concern that membership with ASEAN will hinder the progress of Australia's human rights, it is a possibility. Consequently, Australia is unlikely to provide any significant change in the realms of ASEAN human rights policies. Whilst ASEAN needs to by itself, resolve its human rights policies and how it would behave towards the human rights violations done by its members. ASEAN Way is very much ingrained in the aspect of human rights, where it is advised that it should not be conducted in such a way that halts the promotion and actualization of human rights law throughout the Member States of ASEAN. Additionally, assessment needs to be done in regards to the legal human rights instruments available in ASEAN, and to improve a much more effective dispute settlement mechanism allowing a fair and just decision on disputes relating to human rights violations. Additionally, Severino suggested that:

"In the face of such wide divergences in the situations and conceptions of human rights among ASEAN countries, it is hardly feasible for ASEAN to construct a system for intervening in one another's affairs on the grounds of

78 Frank Frost, Op. Cit., p. 184 
violations of human rights... what ASEAN can do is focus on specific human concerns that all can share, or at least none can publicly reject,...Intensifying collective attention to and cooperation on these common concerns would promote the habit of sharing... It would foster a measure of regional accountability and transparency. ${ }^{.79}$

Concluding that, Australia should maintain its position as a partner of ASEAN and maximize the potential that it already has, strengthening partnership is still very much possible without the need to be a Member State of ASEAN. It would be a much more of a complicated matter if Australia were to be admitted as a member, due to the aforementioned differences in regards to the condition of the Member States and the preferences or stances in various fields including human rights matters, thus making it difficult for Australia in conforming with the required elements of members' admissibility in the ASEAN Charter.

\section{REFERENCES}

\section{Books}

Amer, Ramses and Keyuan Zou, Conflict Management and Dispute Settlement in East Asia, Routledge, United States of America, 2016.

Beckman, Robert (et al.), Promoting Compliance: The Role of Dispute Settlement Mechanisms in ASEAN Instruments, Cambridge University Press, United Kingdom, 2016.

Caballero-Anthony, Mely, Regional Security in Southeast Asia Beyond the ASEAN Way, Institute of Southeast Asian Studies, Singapore, 2005.
Cook, Malcolm and Daljit Singh, Southeast Asian Affairs 2020, ISEAS Publishing, Singapore, 2020.

Davis, Sara E., Legitimising Rejection: International Refugee Law in Southeast Asia, Martinus Nijhoff Publishers, The Netherlands, 2008

Duxbury, Alison and Hsien Li-Tan, Can ASEAN Take Human Rights Seriously?, Cambridge University Press, United Kingdom, 2019.

Frost, Frank Engaging the Neighbours: Australia and ASEAN since 1974, The Australian National University Press, Australia, 2016

Jurgen Haacke, ASEAN's Diplomatic and Security Culture: Origins, Development and Prospects, Routledge Curzon, London, 2003

Kaur, Naginder and Mahyudin Ahmad, Charting a Sustainable Future of ASEAN in Business and Social Sciences, Springer, Singapore, 2020

Narine, Shaun, Explaining ASEAN: Regionalism in Southeast Asia, Lynne Rienner Publishers, United States of America, 2002.

Nasu, Hitoshi et al., The Legal Authority of ASEAN as a Security Institution, Cambridge University Press, Cambridge, 2019

Oishi, Mikio, Contemporary Conflict in Southeast Asia: Towards a New ASEAN Way of Conflict Management, Springer, Singapore, 2016.

Rozbicki, Michal Jan, Human Rights in Translations: Intercultural Pathways, Lexington Books, United States of America, 2018.

Severino, C. Rodolfo, Southeast Asia in Search of an ASEAN Community: Insights from the former ASEAN Secretary-General, Institute of Southeast Asian Studies, Singapore, 2006.

79 Rodolfo C. Severino, Op.Cit., pp. 151-152. 
Australia's Membership in the Association of Southeast Asian Nations in Relation with Human Rights Policies

Tow, William T and Chin Kin Wah, ASEANIndia-Australia: Towards Closer Engagement in a New Asia, Institute of Southeast Asian Studies, Singapore, 2009.

Wood, Sally Percival and Baogang He, The Australia-ASEAN Dialogue, Palgrave Macmillan, United States, 2014.

\section{Other Documents}

Association of Southeast Asian Nations, ASEAN Key Figures 2019, Jakarta, 2019.

Association of Southeast Asian Nations, ASEAN promotes human rights-abiding business practices, https://asean.org/asean-promoteshuman-rights-abiding-businesspractices/

Association of Southeast Asian Nations, ASEAN, Australia Human Rights Commissions to foster closer relations, https://asean.org/asean-australiahuman-rights-commissions-to-fostercloser-relations/

Association of Southeast Asian Nations, Overview ASEAN-Australia Dialogue Relations, April 2017.

Association of Southeast Asian Nations, Plan of Action to Implement the ASEANAustralia Strategic Partnership (20202024), 1 August 2019.

Australian Government Attorney-General's Department, "Right to freedom on opinion and expression", https://www.ag.gov.au/rights-andprotections/human-rights-and-antidiscrimination/human-rightsscrutiny/public-sector-guidancesheets/right-freedom-opinion-andexpression

Australian Government Department of Foreign Affairs and Trade, "Association of Southeast Asian Nations (ASEAN)", https://www.dfat.gov.au/international -relations/regional-
architecture/asean/Pages/associationof-southeast-asian-nations-asean.

Australian Government Department of Foreign Affairs and Trade, "Australia's Strategy for Abolition of Death Penalty", https://www.dfat.gov.au/international -relations/themes/humanrights/Pages/australias-strategy-forabolition-of-the-death-penalty.

Australian Government Department of Foreign Affairs and Trade, ASEANAustralia Counter-Trafficking: Investment Design, March 2018.

Australian Government, ASEAN Now: Insight for Australian Business, A report on Australia's trade and investment relationship with ASEAN, Australia, 2017.

Catherine Shanahan Renshaw, "The ASEAN Human Rights Declaration 2012", Human Rights Law Review, Volume 13, Issue 3, 2013.

Dobell, Grame Australia as a Full ASEAN Community partner, 20 February 2018, https://www.aspistrategist.org.au/aust ralia-full-asean-community-partner/.

Gino J. Naldi and Konstantinos D. Magliveras, "The ASEAN Human Rights Declaration" International Human Rights Law Review, Volume 3, Issue 3, 2014.

Gino J. Naldi, "The ASEAN Protocol on Dispute Settlement Mechanisms: An Appraisal", Journal of International Dispute Settlement, Volume 5, Issue 1, 2014

Hao Duy Phan, "Procedures for Peace: Building Mechanism for Dispute Settlement and Conflict Management with ASEAN", U.C. Davis Journal of International Law \& Policies, Volume 20, Issue 1, 2013.

Hilary Stauffer, "ASEAN and the Evolving State of Human Rights", Social Space, 2011.

Human Rights Watch, "Australia: ASEAN Summit Should Promote Rights", https://www.hrw.org/news/2018/03/1 
4/australia-asean-summit-shouldpromote-rights.

Hunt, Luke "Australia in ASEAN: An EverFloating Idea Without a Clear Case?", https://thediplomat.com/2019/08/aus tralia-in-asean-an-ever-floating-ideawithout-a-clear-case/.

Jacyln L. Neo, "Realizing the Right to Freedom of Thought, Conscience and Religion: The Limited Normative Force of the ASEAN Human Rights Declaration", Human Rights Law Review, Volume 17, Issue 4, 2017.

Keeton-Olsen, Danielle Australia Targets an ASEAN Alliance, But Disagreements Over Human Rights Could Slow Its Progress, https://www.forbes.com/sites/danielle keetonolsen/2018/03/16/australiatargets-an-alliance-with-asean-despitelingering-human-rightsquestions/\#5a82f9855cf1.

Nicholas Doyle, "The ASEAN Human Rights Declaration and The Implications of Recent Southeast Asian Initiatives in Human Rights Institution-Building and Standard Setting", The International and Comparative Law Quarterly, Volume 63, Issue 1, 2014.

Parliament of Australia, The ASEAN-Australia Special Summit, Sydney March 2018: issues and implications, https://www.aph.gov.au/About_Parlia ment/Parliamentary_Departments/Par liamentary_Library/pubs/rp/rp1718/A SEANSummit.

Republic of the Philippines Foreign Service Institute, The Challenges to Australia's ASEAN Membership, http://www.fsi.gov.ph/the-challengesto-australias-asean-membership/.

The Guardian, Indonesia says it would be a 'good idea' for Australia to join ASEAN, https://www.theguardian.com/world/ 2018/mar/16/indonesia-says-it-would- be-a-good-idea-for-australia-to-joinasean.

United Nations High Commissioner for Refugees, Global Appeal 2018-2019, Switzerland, 2018.

United Nations High Commissioner for Refugees, States Parties to the 1951 Convention Relating to the Status of Refugees and the 1967 Protocol, April 2015.

United Nations Human Rights Commissioner for Refugees, Global Trends Forced Displacement in 2018, Switzerland, 2019.

United Nations Human Rights Commissioner, Status of Ratification Interactive Dashboard, https://indicators.ohchr.org.

United Nations Office for the Coordination of Humanitarian Affairs, "Rohingya Refugee Crisis", https://www.unocha.org/rohingyarefugee-crisis.

Zezen Zaenal Mutaqin, "The Rohingya Refugee Crisis and Human Rights: What Should ASEAN Do?", Asia-Pacific Journal on Human Rights and the Law, Volume 19, Issue 1, 2018.

\section{Legal Documents}

Association of Southeast Asian Nations, Charter of the Association of Southeast Asian Nations, 20 November 2007.

Association of Southeast Asian Nations, Joint Statement of the ASEAN-Australia Special Summit: The Sydney Declaration, 18 March 2018.

Association of Southeast Asian Nations, Terms of Reference of ASEAN Intergovernmental Commission on Human Rights, July 2009.

Australian Government Department of Foreign Affairs and Trade, AustraliaAsia Program to Combat Trafficking in Persons (AAPTIP), January 2016. 
Australia's Membership in the Association of Southeast Asian Nations in Relation with Human Rights Policies

United Nations Human Rights Instruments, Reports on indicators for monitoring

rights instruments, UN Doc compliance with international human

$\mathrm{HRI} / \mathrm{MC} / 2008 / 3,6$ June 2008. 